\title{
Immigration of Post Larvae of Penaeid Shrimp to Terminos Lagoon, Campeche, México: 2013 Annual Cycle
}

\author{
César Flores-Coto1, Daniel Embriz-Alba1, Mario Alejandro Gómez-Ponce1, \\ Juana López-Martínez², Laura Sanvicente-Añorve ${ }^{1}$ \\ ${ }^{1}$ Instituto de Ciencias del Mar y Limnologìa, Universidad Nacional autónoma de México, Mexico City, Mexico \\ ${ }^{2}$ Centro de Investigaciones Biológicas del Noroeste S. C., Guaymas, Mexico \\ Email: coto@cmarl.unam.mx
}

How to cite this paper: Flores-Coto, C., Embriz-Alba, D., Gómez-Ponce, M.A., López-Martínez, J. and Sanvicente-Añorve, L. (2018) Immigration of Post Larvae of Penaeid Shrimp to Terminos Lagoon, Campeche, México: 2013 Annual Cycle. Open Journal of Ecology, 8, 522-535. https://doi.org/10.4236/oje.2018.89032

Received: August 21, 2018

Accepted: September 25, 2018

Published: September 28, 2018

Copyright $\odot 2018$ by authors and Scientific Research Publishing Inc. This work is licensed under the Creative Commons Attribution International License (CC BY 4.0).

http://creativecommons.org/licenses/by/4.0/

(c) (i) Open Access

\begin{abstract}
Immigration density magnitude and entry sizes of shrimp postlarvae to Terminos Lagoon were analyzed through sixteen fortnightly sampling from March to November in 2013, in three levels in the deepest channel of the Puerto Real inlet. Trapezium nets were used with $1.5 \mathrm{~m}$ length, $50 \mathrm{~cm}$ mouth diameter and $505 \mu \mathrm{m}$ mesh, during each sampling 12 casts of 15 minutes/each were made. It was determined the presence of two species Litopenaeus setiferus and Farfantepenaeus duorarum, with total densities of 41.284 and 37.558 Pls $100 \mathrm{~m}^{-3}$ respectively. The annual cycle of immigration of postlarvae was very similar for both species, with a clear pattern of immigration throughout the year, linked to climatic variation, with the highest densities (88\%) during rainy season. There were two periods of maximum density, related to the periods of greatest reproduction of these species. The density variation among cast reflects the presence of at least two and probably more postlarvae banks, located some closer than others to the mouth of the lagoon and with different densities in them. The average sizes of the two species were $7.9 \mathrm{~mm}$ total length of $L$. setiferus and $9.0 \mathrm{~mm}$ of $F$. duorarum. The differences in income sizes of both species seem to indicate the habitat preference of adult populations, L. setiferus occurring in more coastal areas than F. duorarum. Considering the variation in density and sizes throughout each sampling period, it is evident that the larvae on the banks belong to different cohorts and that have coincided in their location in front of the mouth.
\end{abstract}

\section{Keywords}

Shrimp, Immigration, Magnitude, Sizes 


\section{Introduction}

Shrimp fishing in the Campeche Bay represented an important economic resource, although it has been in crisis since the beginning of the Century [1]. However, the reduction of its catch remains a resource with relative importance on the coast of the Gulf of Mexico and the Caribbean Sea [2].

In the area of the Gulf of Mexico, there are three species with the greatest fishing importance: white shrimp, Litopenaeus setiferus (Linnaeus, 1767), pink shrimp, Farfantepenaeus duorarum (Burkenroad, 1939) and brown shrimp, Farfantepenaeus aztecus (Ives, 1891). Within the Campeche Bay, Terminos Lagoon is an important breeding area for several organisms including the penaeid shrimp [3].

The penaeid postlarvae immigration to the nursery areas has been studied in many parts of the world attending the effects of currents and climatic seasons on the transport processes; [4]-[9].

For the Gulf of Mexico it could be mentioned the paper of Rogers et al. [7] Criales et al. [10], Criales et al. [11], Flores-Coto et al. [12]. Particularly for Puerto Real inlet, study area, in Terminos Lagoon, Campeche, can be referred to the works of Gracia and Soto [3] and the professional theses of Arenas-Mendieta and Yáñez-Martínez [13], Alarcón-Daowz [14] which give the first idea of immigration of postlarvae to the lagoon, observing that occurs throughout the year, with maxima in July and September and that $F$. duorarum and L. setiferus are the species that enter to the lagoon.

The most recent paper is from Gómez-Ponce et al. [15] who assessed the entry of postlarvae of white shrimp L. setiferus, during an annual cycle in 2010, and mentioned that the highest density period occurs from June to September; the paper of Gómez-Ponce et al. [15] is the immediate antecedent of this paper, as they are part of a larger project whose objective is to monitor and evaluate the immigration of shrimp postlarvae to the Terminos lagoon for a decade.

The success of future generations of adults is certainly closely linked to the size of the populations of postlarvae entering the breeding area, so monitoring will result in important information that can contribute to a better and more efficient management of this important fishery, allowing to estimate possible future densities of adults.

In this sense Rámirez-Rodríguez [1] in his work on the historical development and perspectives of the shrimp fishery in Campeche, mentions that the shrimp fishery in the sea is in crisis since 2000 and that it is necessary to implement proposals to Fisheries Administration, which in our concept require information derived from a monitoring that evaluates the immigration of postlarvae to the breeding areas, in particular to Terminos lagoon.

Therefore the objective of this work is to determine the density magnitude of immigration of postlarvae of Penaeid shrimp and their sizes of entry to Terminos Lagoon through the Puerto Real inlet, during of higher flow velocity period, from March to November of 2013. 


\section{Study Area}

Terminos lagoon is located at the southeast of the Gulf of Mexico in Campeche State, is separated from the Campeche Bay by the Carmen island and connected by two inlets to the marine environment, the Carmen inlet at its western end with a width of $3.8 \mathrm{~km}$ and the Puerto Real inlet, sampling site of this work, at the eastern end of the lagoon with a width of $3.2 \mathrm{~km}$ (Figure 1 ). To the lagoon flows three rivers: Candelaria, Chumpán, and Palizada with an important contribution of organic matter and fresh water.

The tides generate a general circulation that leads to a net flow East-west penetrating the greater volume of seawater by Puerto Real inlet, leaving mainly by the Carmen inlet [16] [17] [18] [19].

\section{Material and Methods}

Sixteen fortnightly sampling were made from March to November 2013, which were programmed through the tide calendar of the Instituto de Geofisica (UNAM). In July and September, only one sampling was carried out (Table 1).

The sampling point was established in the deepest channel of the Puerto Real inlet. The management of the equipment was carried out from the base of one of the piles of the bridge. The collections were carried out during the period of high

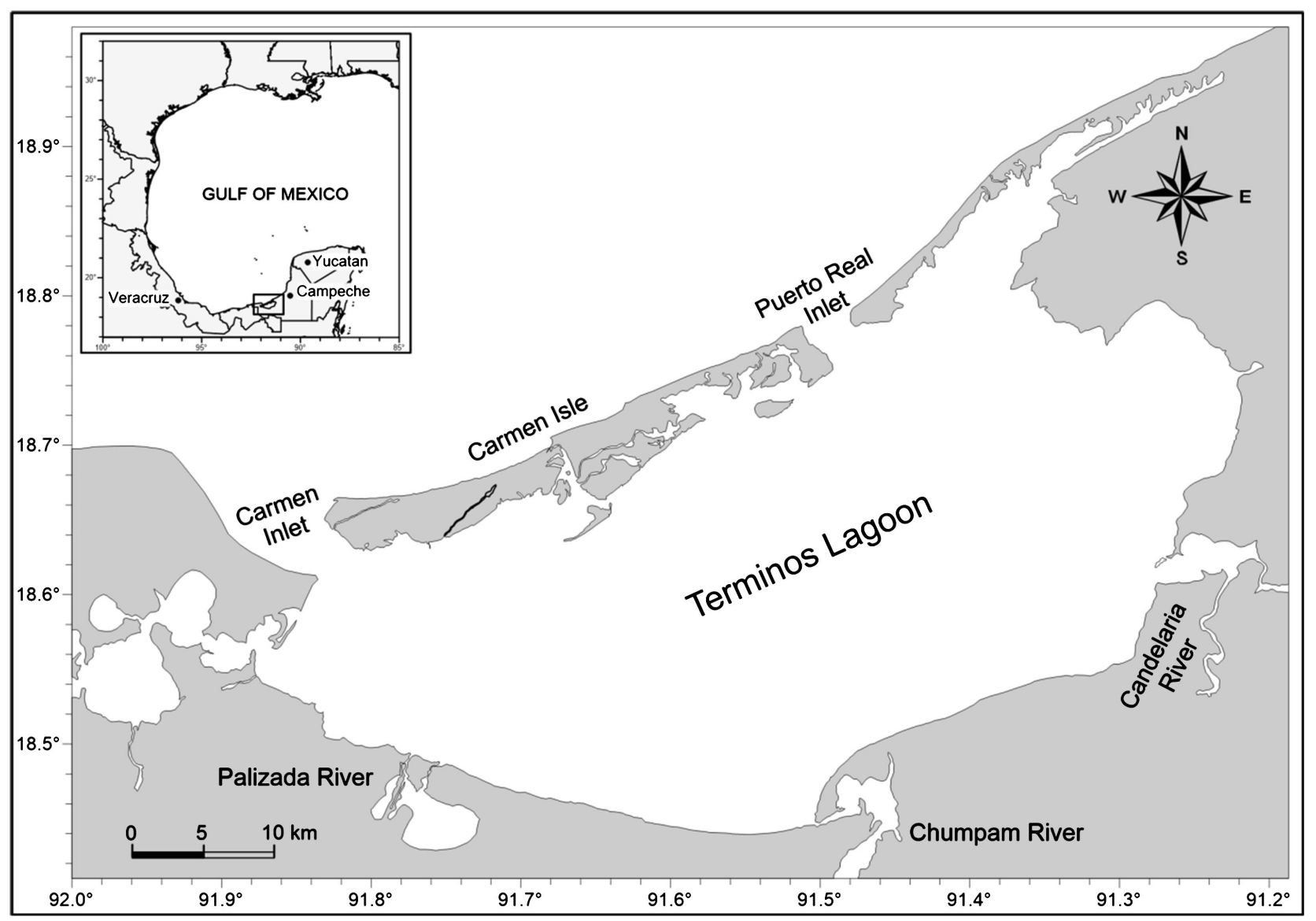

Figure 1. Puerto Real inlet, study area, in Terminos Lagoon, Campeche, Mexico. 
Table 1. Sampling dates, March to November 2013.

\begin{tabular}{cccc}
\hline Collection number & Date & Collection number & Date \\
\hline 1 & March 7 & 9 & July 29 \\
2 & March 18 & 10 & August 15 \\
3 & April 18 & 11 & August 29 \\
4 & April 30 & 12 & September 30 \\
5 & May 14 & 13 & October 11 \\
6 & May 28 & 14 & October 24 \\
7 & June 10 & 15 & November 15 \\
8 & June 24 & 16 & November 30 \\
\hline
\end{tabular}

current speed, that is, when the speed was equal or greater than $0.5 \mathrm{~m} / \mathrm{s}$.

During each fortnightly sampling, 12 casts of 15 minutes each were made, simultaneously in three depths: surface $(0.5 \mathrm{~m})$ mid water $(5 \mathrm{~m})$ and bottom (12 $\mathrm{m})$. Trapezium nets were used of $1.5 \mathrm{~m}$ in length, $50 \mathrm{~cm}$ in mouth diameter and $505 \mu \mathrm{m}$ mesh [20]. Samples were preserved in $4 \%$ formalin neutralized with sodium borate.

To estimate the filtered volume, a flowmeter (General Oceanic) was placed in the mouth of each net and the salinity and temperature data were obtained with a YSI 30 thermo-salinometer.

In the laboratory, samples were transferred to alcohol to $70 \%$ for their preservation. All postlarvae were extracted from each sample, measured (total length) and identified at the species level, except those less than $6 \mathrm{~mm}$.

The number of postlarvae (PLs) was standardized to 100 cubic meters (PLs $\left.100 \mathrm{~m}^{-3}\right)$.

Analysis of variance (one-way ANOVA) was made to establish whether there were statistically significant differences in postlarvae densities between the three sampled levels, between the average densities and sizes of the identified species to meet the assumptions of normalcy, the density data were transformed to Ln $(\mathrm{X}+1)$ and the homoscedasticity of variances was tested by means of a Barttlet test. A Spearman regression analysis was applied between Pls average densities and temperature and salinity averages, of each fortnightly sampling.

\section{Results}

\section{Density magnitude and immigration cycle of postlarvae}

There were captured 69.660 postlarvae and take out the dot March to November in 576 samples obtained during 16 fortnightly samplings.

It was determined the presence of two species Litopenaeus setiferus and Farfantepenaeus duorarum, with total densities throughout the collection cycle of 41.284 and $37.558 \mathrm{Pls} 100 \mathrm{~m}^{-3}$ respectively; 2019 specimens with sizes less than 6 $\mathrm{mm}$ could not be identified.

The analysis of variance (one-way ANOVA) indicated that there were no sig- 
nificant differences between surface, mid and bottom water densities of pink shrimp postlarvae $(\mathrm{F}=3.014, \mathrm{~F} 0.05(2.573)=0.587, \mathrm{p}>0.05)$, and white shrimp postlarvae $(\mathrm{F}=3.014, \mathrm{~F} 0.05(2.573)=2.376, \mathrm{p}>0.05)$, so hereafter we will refer to the density as its average value.

During the sampling cycle, two periods of maximum density of both species were presented, the first occurred on June 10 and the second on September 30, with clearly lower densities between these two periods although the lowest occurred at the beginning and end of sampling period (Figure 2).

The annual cycle of immigration of postlarvae was very similar for both species, there were, however small differences in their densities during the months of greater abundance, the density of $F$. duorarum was slightly higher in June and that of L. setiferus in August and September (Figure 2).

\section{Density variation between cast and collection seasons}

The densities of the 576 samples show the lowest values occurring during the first three, the last two and the seventh casts; the latter between two high-density periods, the first with the largest values during casts 4 to 6 and the second from 8 to 10 (Figure 3).

When analyzing the postlarvae entrance of each species per cast during, rainy, dry and cold fronts seasons (Cold fronts hereafter, north season) it is observed that the higher density occurs in rainy season, (June to September), on the other hand during dry (march to May) and north (October to November) seasons, the densities were extremely low for both species, therefore the two periods of higher density during casts $4-6$ and $8-10$ reflect what happened in the time of greatest abundance in the rainy season, but did not occur on the same sampling date (Figure 4).

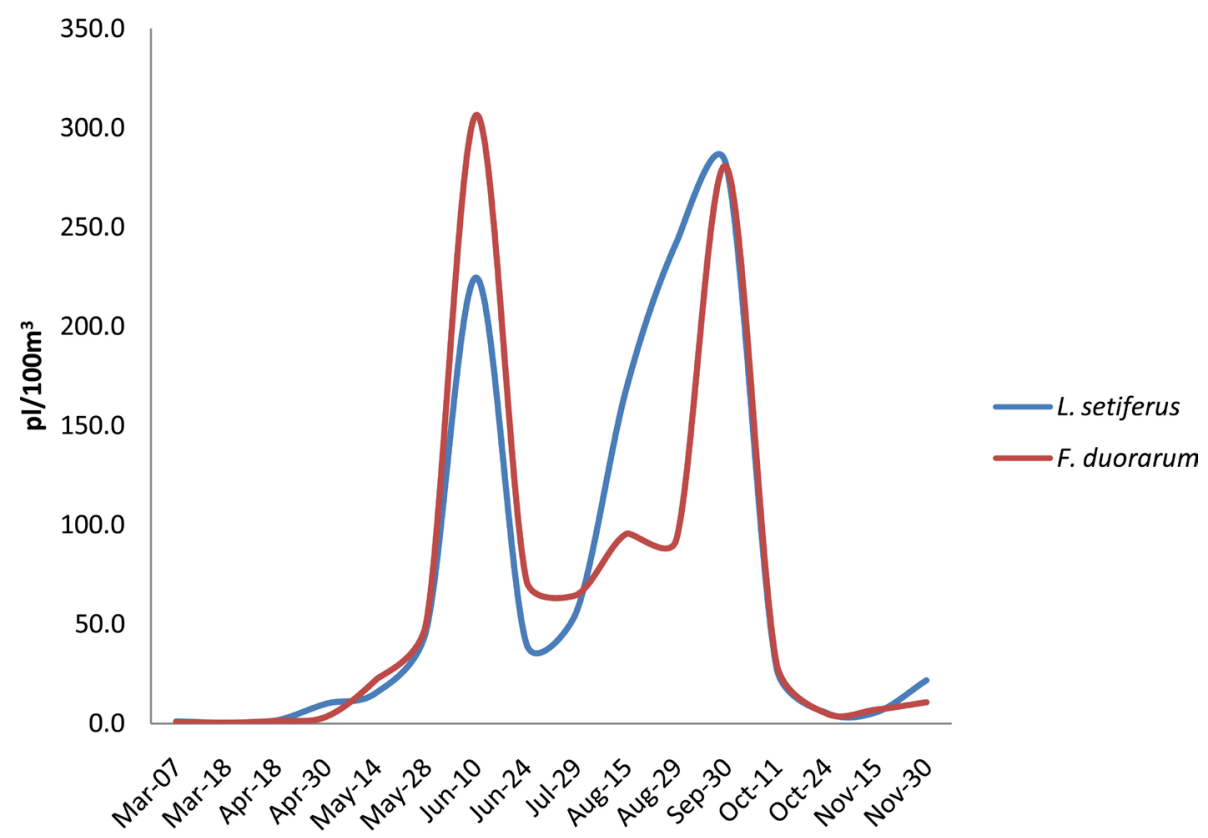

Figure 2. Postlarvae average densities of $F$. duorarum and L. setiferus immigrating to Terminos Lagoon though Puerto Real inlet, from March to November 2013. 


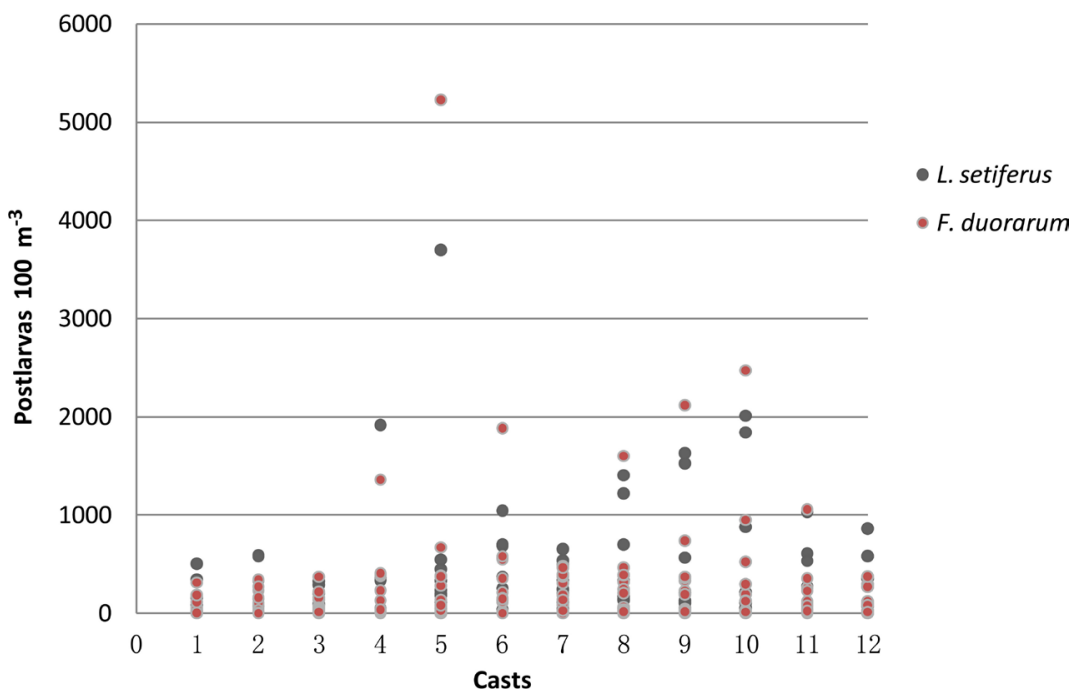

Figure 3. Postlarvae density in each cast during the 16 sampling periods.
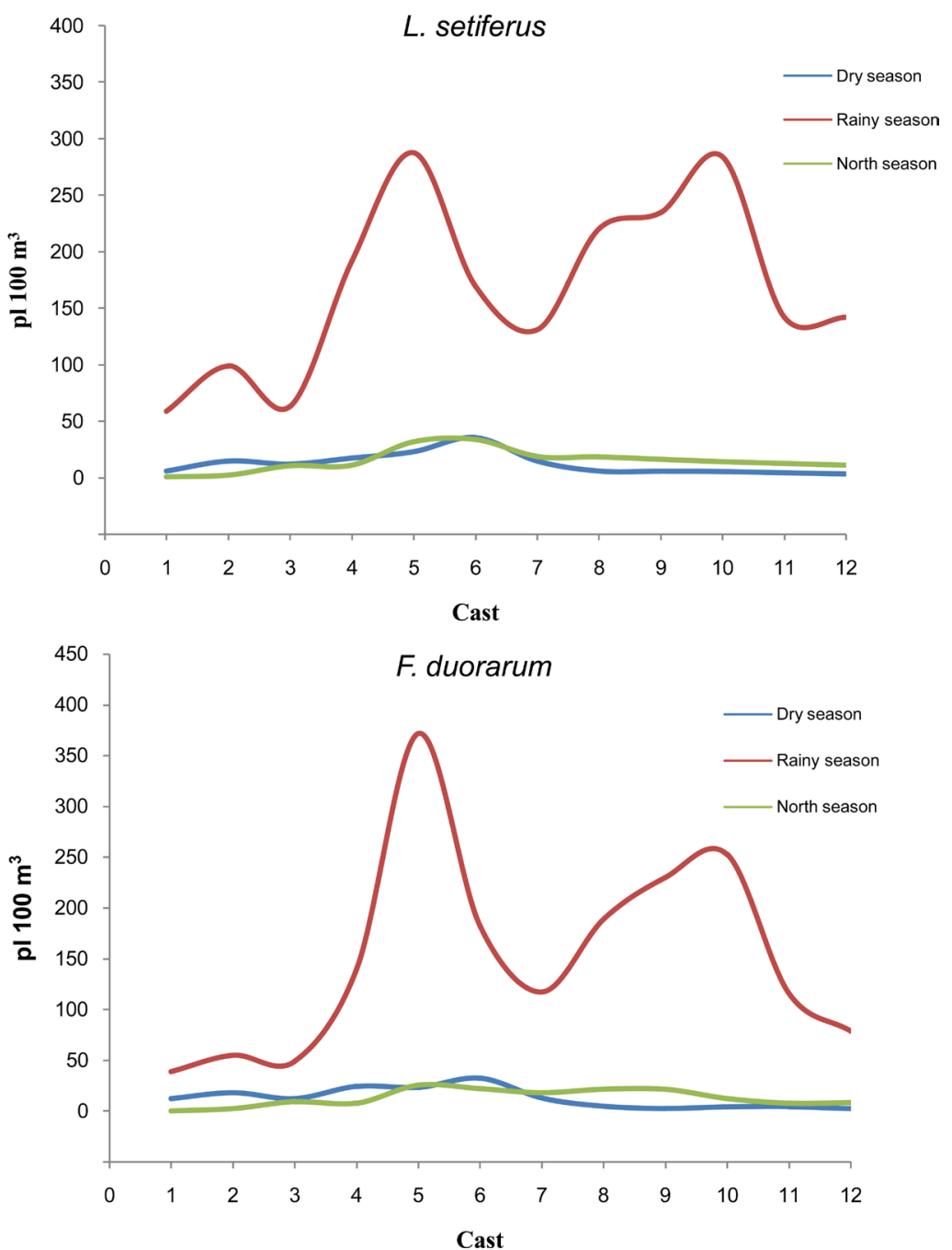

Figure 4. Cast average density of L. setiferus and F. duorarum postlarvae, during different seasons. The rainy season, June to September; dry season, March to May and north season, October to November. 


\section{Sizes}

The average sizes of the two species were different $7.9 \mathrm{~mm}$ of $L$. setiferus and $9.0 \mathrm{~mm}$ of $F$. duorarum.

The size variation throughout the sampling period was also different for each species; F. duorarum except for relatively large sizes in March and beginning of April, presented a clearing increased from the second sampling from April to November when the maximum average size of $10.3 \mathrm{~mm}$ was recorded, although the maximum individual size was $14.6 \mathrm{~mm}$ (Figure 5).

For L. setiferus can be considered three periods of entrance according to their sizes, one since March with sizes relatively large until early April, from late April with the sizes smaller $(7.3 \mathrm{~mm})$ is increased until June and decrease until September when the second lowest average size of $7.4 \mathrm{~mm}$ was registered, then the size increase until November (Figure 6).

\section{Temperature}

The annual average temperature was $28.3^{\circ} \mathrm{C}$, with maximum and minimum values of $31.9^{\circ} \mathrm{C}$ and $23.5^{\circ} \mathrm{C}$, respectively.

The sampling cycle starts with low values, gradually increasing until the first sampling of August and then gradually descended until the end of the period (Figure 7). Variations in each sampling date were small.

A positive linear relationship was found between the temperature and postlarvae density for the two recorded species, with values of $\mathrm{r}=0.60$ for $F$. duorarum and $\mathrm{r}=0.57$ for $L$. setiferus.

\section{Salinity}

Salinity values reached an annual average of 32.9 and minimum and maximum values of 14.1 and 39.1 respectively.

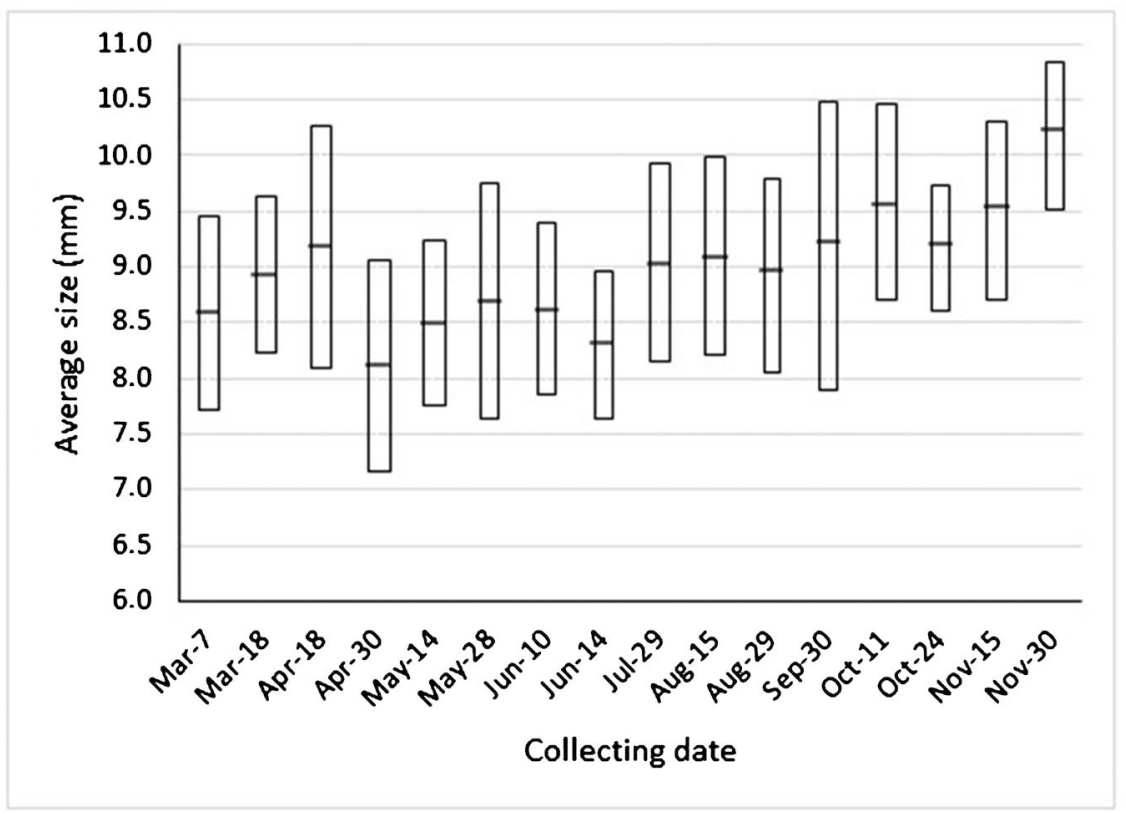

Figure 5. Average size variation and standard deviation of $F$. duorarum postlarvae, through the sampling period. 


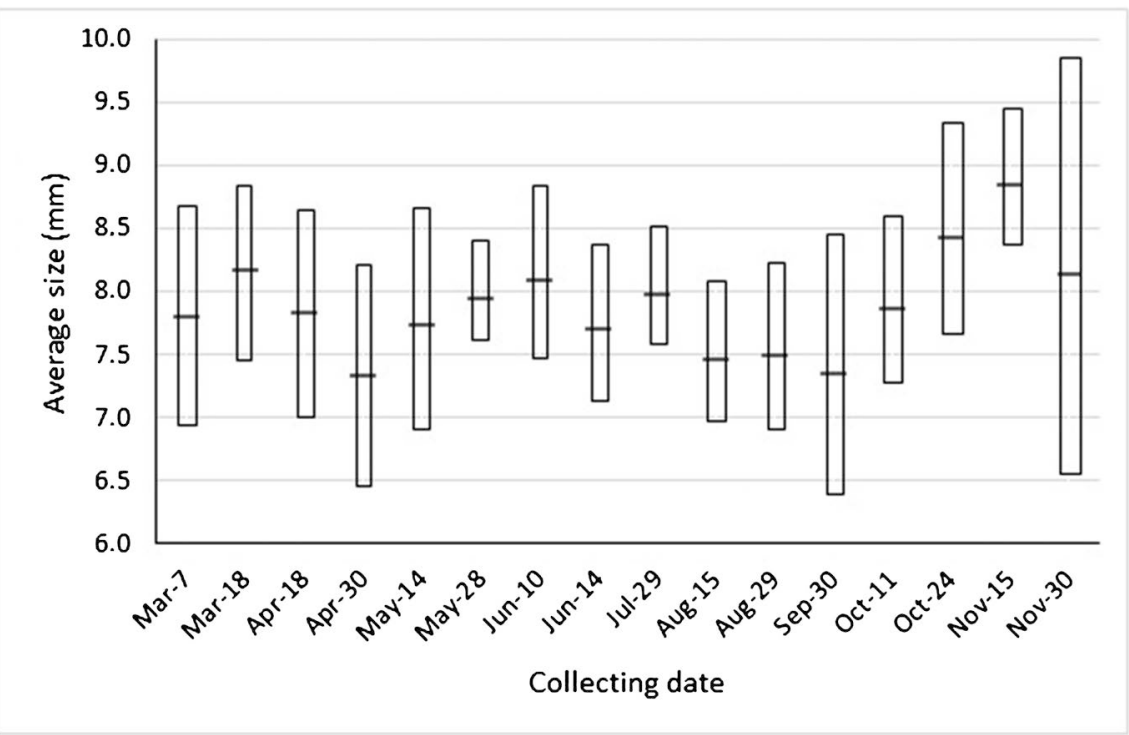

Figure 6. Average size variation and standard deviation of $L$. setiferus postlarvae, through the sampling period.

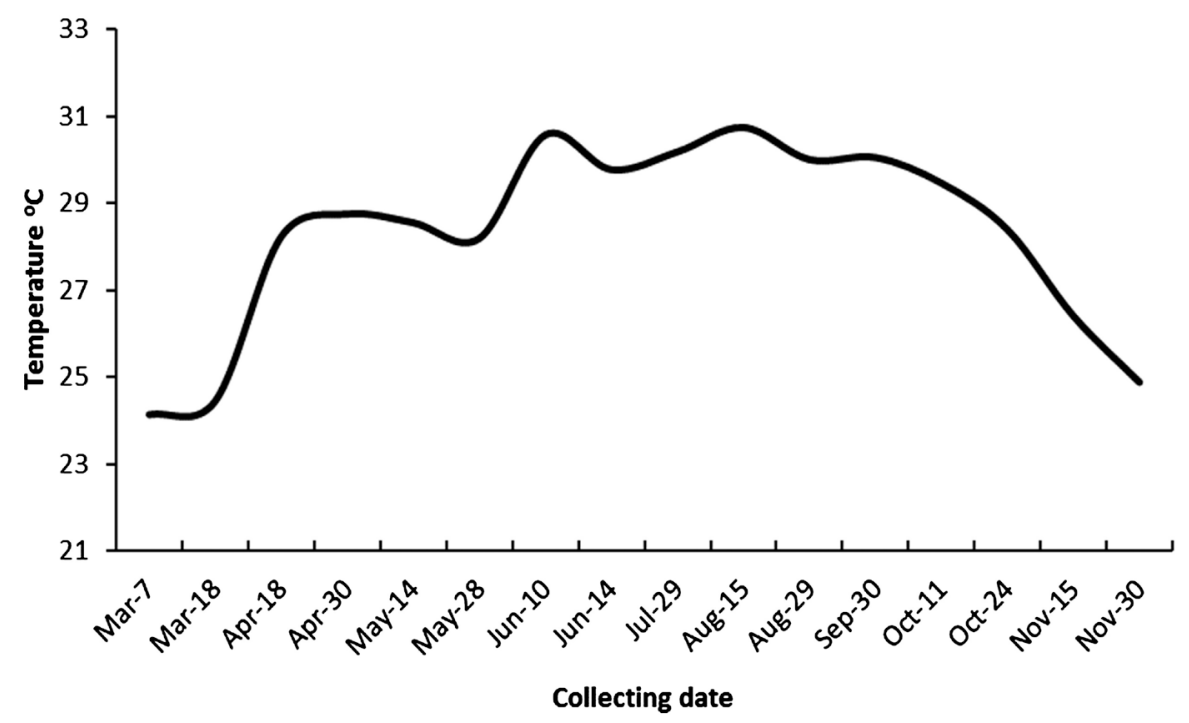

Figure 7. The annual variation of average temperature through sampling period.

Its annual cycle starts with high values until the first fortnight of July, from where it presented a gradual descent until reaching the lowest in the last sampling of November. Whit some exception the variations in each sampling date were small (Figure 8). No relationship was found between salinity and the postlarvae density for either of the two species.

\section{Discussion}

\section{Density magnitude and pattern of postlarvae immigration}

Postlarvae of two species $L$. setiferus and $F$. duorarum were recorded; and according to previous works [3] together with $F$. aztecus are the dominant species among the penaeid of the area. 


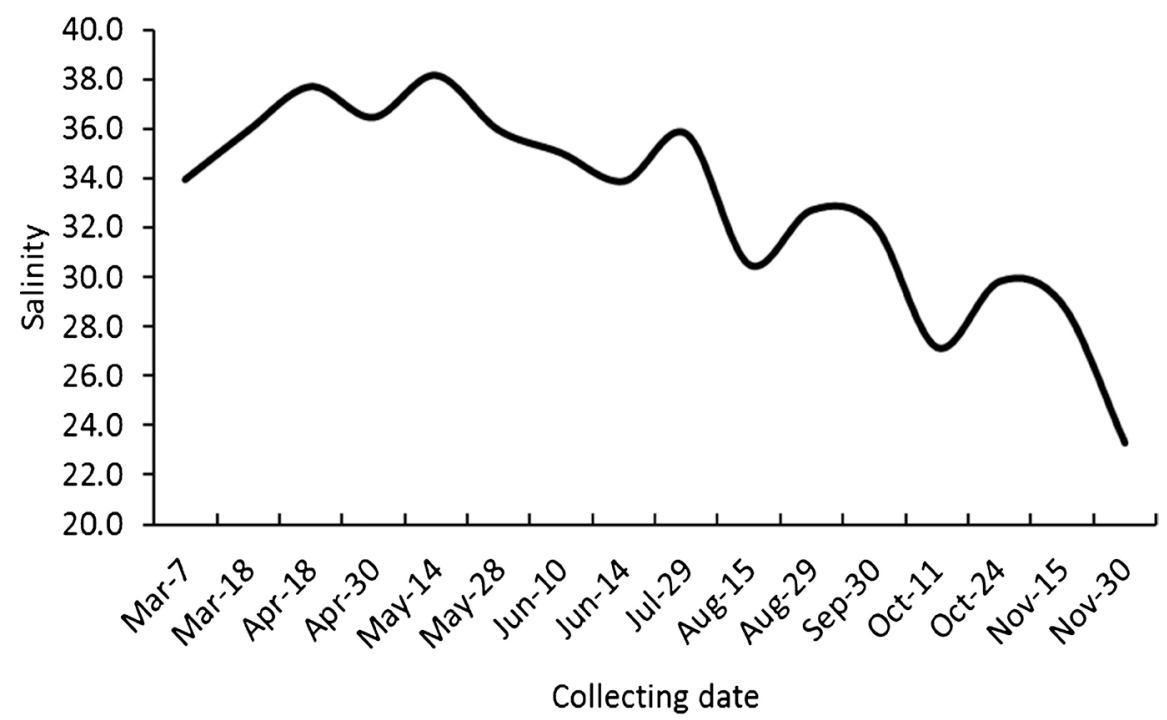

Figure 8. Annual variation of average salinity through sampling period.

The magnitude of immigration from March to November, in absolute numbers was $69,660 \mathrm{Pls}$ which corresponded $41,284 \mathrm{Pls} 100 \mathrm{~m}^{-3}$ to L. setiferus and $37,558 \mathrm{Pls} 100 \mathrm{~m}^{-3}$ to $F$. duorarum.

The results show that there is a clear pattern of immigration of postlarvae to the Terminos lagoon throughout the year, linked to climatic variation, with the highest densities (88\%) during rainy season and high temperatures, while the rest of the year density values were very low. The results fit with the fact that the shrimp spawning cycle according with Gracia and Soto, [21], Gracia and Soto [3], Re-Regis, [22], Gracia et al. [23] is uninterrupted throughout the year but with clear increases in the rainy season.

Two periods of maximum density were recorded in one in June and other in September that are consistent with previous results; [3] [13] [14] [15]. The periods of maximum density are necessarily related to the periods of greatest reproduction of these species, as mentioned by Gracia and Soto [21]; Re-Regis, [22].

During the sampling cycle, the density of $F$. duorarum was slightly higher than that of L. setiferus from May to June but lower in August and September. These differences can be attributed to a greater or lesser concentration of reproducers at different times. According to Fuentes et al. [24] the abundance of $F$. duorarum at least for that decade was greater than $L$. setiferus.

Soto and Gracia [25] found seasonal variations with different centers of adult concentration. Although populations overlap, it can be generalized that the major areas of concentration of $F$. duorarum occur from the north-eastern portion of Terminos lagoon to the northwest, in the carbonated province of the Campeche Bay, in areas not very coastal, the highest concentrations of L. setiferus occur from El Carmen inlet to the west, in a silt-clay province, in very shallow areas [22] [24] [25].

This adult populations distribution could help to explain why Flores-Coto et 
al. [12] recorded a much more higher postlarvae density of $L$. setiferus $(13.332$ $\left.\mathrm{PL} / 100 \mathrm{~m}^{3}\right)$ than $F$. duorarum, $\left(2.198 \mathrm{PL} / 100 \mathrm{~m}^{3}\right)$ in the Santana inlet of the Carmen and Machona lagoons, located west of the Terminos lagoon where it can found high concentration of $L$. Setiferus adults.

It could be also considered the variability among years. The obtained postlarvae average by sample $120.9 \mathrm{Pls}$ in this work compared with average 147.9 Pls obtained by Gómez-Ponce et al. [15] must be result of such variability. Matthews [26] found great variability between years when estimating postlarvae density migrating to Galveston Bay, Texas.

On the other hand with different methodologies and a complete annual cycle, Arenas-Mendieta and Yáñez-Martínez [13] recorded only $4.740 \mathrm{Pls}$, and Alarcón-Daowz [14] 1.977 Pls. These differences make it clear that sampling methodology has an important role to play in evaluating the magnitude of immigration.

\section{Postlarvae density, temperature and salinity}

The obtained data show that there is no relationship between temperature and salinity with the entrance of Postlarvae to the lagoon during each sampling date, however, analyzing immigration throughout the year, it becomes evident a strong correlation between the postlarvae density and the highest temperatures recorded throughout the annual cycle $(\mathrm{r}=0.778$, F. duorarum; $\mathrm{r}=0.778$, L. setiferus).

The two periods with the highest density of postlarvae (10 June and 30 September) occurred in temperatures from $29.7^{\circ} \mathrm{C}$ to $30.8^{\circ} \mathrm{C}$, similarly Gómez-Ponce et al. [15] during main immigration period from May to September recorded temperatures higher than $29^{\circ} \mathrm{C}$.

Salinity did not show a statistically significant correlation with the immigration of postlarvae, nor during each sampling or during the year, however, it seems to have an indirect effect, since it is clear the increase in density of postlarvae in the period that decreases the salinity. Boehlert and Mundy [6] point out that a decrease in salinity serves as a clue to begin the immigration of some organisms. The low salinity is the result of continental waters the discharges, which promotes high primary and secondary production and therefore constitutes the source of food for adults and larvae.

\section{Variation of the postlarvae density between casts and sampling season}

The concentration of postlarvae of Penaeid in front of the mouth of rivers and estuarine bodies before penetrating to its breeding area, has been previously reported for several parts of the world [4] [6] [7] [8] [9].

The density of postlarvae over 12 casts in the each of 16 samples periods shows that the lower values were recorded in the first and last casts with two periods of high density between the casts 4 and 10, although they did not occur in the same sampling date (Figure 3, Figure 4). These maxima should reflect the presence of at least two and probably more postlarvae banks, located some closer than others to the mouth of the lagoon and with different densities in them, fact 
of which generate the differences in the individual collections.

These results indicate that the higher densities enter about two hours after the tidal flow has begun, which coincides with the described by Young and Carpenter [4] and Rothlisberg et al. [8]. Similar results obtained Flores-Coto et al. [12] and Gómez-Ponce et al. [15] which determined that the higher densities enter in the few hours after of the onset of tidal flow.

\section{Postlarvae size variation}

The results show that the average length (Figure 5) of L. setiferus $(7.9 \mathrm{~mm})$ throughout the year were always lower than those of $F$. duorarum $(9.0 \mathrm{~mm})$ which can be attributed to the more coastal distribution of the adult populations of the former [22] [24] [25]. This fact supposes that the migration of larvae of $L$. setiferus to the mouth of the lagoon is earlier and in stages less developed than the larvae of $F$. duorarum.

Similarly Baxter and Renfro [27] reported inr Galveston Texas Bay, that the income sizes of $L$. setiferus are lower than those of $P$. aztecus, which seems to indicate the preference of adult populations of $L$. setiferus by more coastal areas and $F$. duorarum and P. aztecus for less coastal and deeper areas, as Soto and Gracia [25] point out.

The largest sizes of both species were observed at the end of the sampling cycle, in the north season, this can be attributed independently of the location of the reproducers populations, to the movement of coastal waters to ocean area, a consequence of the collision of the Yucatán shelf current and Veracruz coastal current [28] this fact it means more time for the planktonic larvae to locate near the mouth and consequently the arrival of postlarvae with greater sizes to the lagoon.

It can be generalized that the variation of sizes during its immigration to the lagoon is the result of the distance to the adult populations to the inlet and the direction of the currents. Considering the sizes variation throughout each sampling period, it is evident that the larvae on the banks belong to different cohorts and that have coincided in their location in front of the mouth.

The sizes of the postlarvae immigrating to the breeding areas after passing through their planktonic stages, appear to be similar in most of the different penaeid shrimp species in the world; varying between 5 and $14 \mathrm{~mm}$ approximately: Macias-Regalado and Calderón-Pérez [29] in the Mexican Pacific, Forbes and Benfiel [30] in Natal, South Africa; Baxter and Renfro [27] Allen et al., [31] in Galveston, USA, Criales et al. [32] in Florida; USA, Young and Carpenter, [4] Rothlisberg et al., [8] in Eastern Australia; Blanton et al., [33] in the North Atlantic, Flores-Coto et al. [12] in the Southern Gulf of Mexico.

We assume that regardless of the distance to the Lagoon mouths of the reproducers and the currents involved in the transport, there seems to be a time limit for shrimp postlarvae to reach the epibenthic stage, to enter to the breeding area.

\section{Acknowledgements}

The authors thank the Instituto de Ciencias del Mar y Limnología (UNAM) for 
the financing of this project, and a great recognition to Hernán Alvarez and Andrés Reda without whose help we could not have carried out the samplings.

\section{Conflicts of Interest}

The authors declare no conflicts of interest regarding the publication of this paper.

\section{References}

[1] Ramírez-Rodríguez, M. (2015) La pesqueria del camarón en Campeche: Desarrollo historico y perspectiva. Ciencia Pesquera, 23, 73-87.

[2] CONAPESCA (2013) Anuario estadístico de acuacultura y pesca 2013. Comisión Nacional de Acuacultura y Pesca, Secretaria de Agricultura, Ganaderia, Desarrollo Rural, Pesca y Alimentación, Mexico.

[3] Gracia, G.A. and Soto, G.L.A. (1990) Populations Study of the Penaeid Shrimp of Términos Lagoon, Campeche, México. Anales del Instituto de Ciencias del Mar y Limnología, 17, 241-255.

[4] Young, P.C. and Carpenter, S.M. (1977) Recruitment of Postlarval Penaeid Prawns to Nursery Areas in Moreton Bay, Queensland. Marine and Freshwater Research, 28, 745-773. https://doi.org/10.1071/MF9770745

[5] Calderón-Pérez, J.A. and Poli, C.R. (1987) A Physical Approach to the Postlarval Penaeus Immigration Mechanism in a Mexican Coastal Lagoon (Crustacea: Decapoda: Penaeidae). Anales del Instituto de Ciencias del Mar y Limnología, 14, 147-156.

[6] Boehlert, G.W. and Mundy, B.C. (1988) Roles of Behavioral and Physical Factors in Larval and Juvenile Fish Recruitment to Estuarine Nursery Areas. American Fisheries Society Symposium, 3, 51-67.

[7] Rogers, B.D., Shaw, R.F., Herke, W.H. and Blanchet, R.H. (1993) Recruitment of Postlarval and Juvenile Brown Shrimp (Penaeus aztecus Ives) from Offshore to Estuarine Waters of the Northwestern Gulf of Mexico. Estuarine, Coastal and Shelf Science, 36, 377-394. https://doi.org/10.1006/ecss.1993.1023

[8] Rothlisberg, P.C., Church, J.A. and Fandry, C.B. (1995) A Mechanism for Near-Shore Concentration and Estuarine Recruitment of Post-Larval Penaeus plebejus Hess (Decapoda, Penaeidae). Estuarine, Coastal and Shelf Science, 40, 115-138. https://doi.org/10.1016/S0272-7714(05)80001-0

[9] Criales, M.M., Robblee, M.B., Browder, J.A., Cadenas, H. and Jackson, T.L. (2010) Nearshore Concentration of Pink Shrimp (Farfantepenaeus duorarum) Postlarvae in Northern Florida Bay in Relation to Nocturnal Flood Tide. Bulletin of Marine Science, 86, 53-74.

[10] Criales, M.M., Wang, J., Browder, J.A. and Robblee, M.B. (2005) Tidal and Seasonal Effects on Transport of Pink Shrimp Postlarvae. Marine Ecology Progress Series, 286, 231-238. https://doi.org/10.3354/meps286231

[11] Criales, M.M., Robblee, M.B., Browder, J.A., Cardenas, H. and Jackson, T.L. (2011) Field Observations on Selective Tidal-Stream Transport for Postlarval and Juvenile Pink Shrimp in Florida Bay. Journal of Crustacean Biology, 31, 26-33. https://doi.org/10.1651/10-3291.1

[12] Flores-Coto, C., Becerril-Martínez, J.A., Zavala-García, F., Gracia, A. and Burke, J. (2010) Inmigración de larvas de camarón durante el periodo de mayor velocidad de flujo de marea en el sur del Golfo de México. Hidrobiológica, 20, 1-12. 
[13] del Arenas-Mendieta, M.R. and Yáñez-Martínez, A. (1981) Patrón anual de inmigración de postlarvas de camarón (Crustacea: Decapoda; Penaeidae), en la Boca de Puerto Real, Laguna de Términos, Campeche. Professional Thesis, Facultad de Ciencias, Universidad Nacional Autónoma de México, México.

[14] Alarcón-Daowz, G. (1986) Estratificación de las postlarvas planctónicas de camarones peneidos durante la inmigración a través de la Boca de Puerto Real, Laguna de Términos. Professional Thesis, Facultad de Ciencias, Universidad Nacional Autónoma de México, México.

[15] Gómez-Ponce, M.A., Flores-Coto, C., López-Martínez, J., Cruz-Sánchez, J.L. and Sanvicente-Añorve, L. (2018) Evaluation of the Entry of White Shrimp Postlarvae (Decapoda: Penaeidae) to a Nursery Area in the Southern Gulf of Mexico. Latin American Journal of Aquatic Research, 46, 1-10.

[16] Gierloff-Emdem, H.G. (1977) Laguna de Terminos and Campeche Bay, Gulf of Mexico, Water Mass Interaction Lagoonal Oceanic Visible Due 10 Sediments Landed Waters. In: Gierloff-Emden, H.G., Ed., Orbital Remote Sensing Coast and Offshore Environment, Walter de Gruyter, Berlin, 77-89.

[17] Mancilla-Peraza, M. and Vargas-Flores, M. (1980) Los primeros estudios sobre la circulación y el flujo neto de agua a través de la Laguna de Términos, Campeche. Anales del Centro de Ciencias del Mar y Limnologia, UNAM, 7, 1-2.

[18] Graham, D.S., Daniels, J.P., Hill, J. and John, A.W. (1981) A Preliminary Model of the Circulation of Laguna de Términos, Campeche, México. Anales del Instituto de Ciencias del Mar y Limnología, UNAM, 8, 51-61.

[19] Kjerfve, B., Magill, K.E. and Sneed, J.E. (1988) Modeling of Circulation and Dispersion in Terminos Lagoon. In: Yáñez-Arancibia, A. and Day Jr., W.J., Eds., Ecology of Coastal Ecosystems in Southern Gulf of Mexico in the Terminos Lagoon Region México, Editorial Universitaria, México D.F., 111-138.

[20] Flores-Coto, C. and Zavala-García, F. (1994) Un nuevo sistema para muestreo simultáneo de zooplancton en varios niveles, para zonas someras. Anales del Instituto de Ciencias del Mar y Limnología, UNAM, 21, 149-153.

[21] Gracia, A. and Soto, L. (1986) Condiciones de reclutamiento de las poblaciones de camarones peneidos en un sistema lagunar-marino tropical: Laguna de Términos-Banco de Campeche. IOC/FAO Workshop on Recruitment in Tropical Coastal Demersal Communities, 257-265.

[22] Re-Regis, M.C. (1996) Estacionalidad de la reproducción del camarón blanco Penaeus setiferus en la Sonda de Campeche. Ciencia Pesquera, 12, 35-39.

[23] Gracia, A., Vázquez-Bader, A.R., Arreguín-Sánchez, F., Schultz-Ruiz, L.E., Sánchez, J.A., Flores-Hernández, D., Sánchez-Gil, P., Seijo, J.C. and Arreguín-Sánchez, F. (1997) Ecología de camarones peneidos. Análisis y diagnóstico de los recursos pesqueros críticos del Golfo de México, 7, 127-144.

[24] Fuentes, D., Castro, R., Schultz, L., Portugal, R. and Oropeza, M. (1976) Pesquería de camarón de altamar en el Golfo de México. Memorias del Simposio sobre biología y dinámica poblacional de camarones, Guaymas, 8-13.

[25] Soto, L.A. and Gracia, A. (1987) Evaluación de los efectos de hidrocarburos fosiles sobre las poblaciones de camarones peneidos en el Banco de Campeche. Anales del instituto de Ciencias del Mar y Limnologia UNAM, 14, 133-146.

[26] Matthews, G.A. (2008) Variability in Estimating Abundance of Postlarval Brown Shrimp, Farfantepenaeus aztecus (Ives), Migrating into Galveston Bay, Texas. Gulf and Caribbean Research, 20, 29-39. https://doi.org/10.18785/gcr.2001.05

[27] Baxter, K.N. and Renfro, W.C. (1966) Seasonal Occurrence and Size. Distribution of 
Postlarval Brown and White Shrimp near Galveston, Texas, with Notes on Species Identification. Fishery Bulletin, 66, 149-158.

[28] Zavala-Hidalgo, J., Morey, S.L. and O’Brien, J.J. (2003) Seasonal Circulation on the Western Shelf of the Gulf of Mexico Using a High-Resolution Numerical Model. Journal of Geophysical Research, 108, 1978-2012. https://doi.org/10.1029/2003JC001879

[29] Macias-Regalado, E. and Calderón-Pérez, A. (1979) Talla de inmigración de postlarvas de camarón al sistema lagunar Huizache-Caimanero, Sinaloa, México. (Crustacea, Decapoda, Penaeus). Anales del Centro de ciencias del Mar y Limnologia, UNAM, 6, 99-106.

[30] Forbes, A.T. and Benfield, M.C. (1986) Tidal Behavior of Postlarval Penaeid Prawns (Crustacea: Decapoda: Penaeidae) in a Southeast African Estuarry. Journal Experimental Marine Biology Ecology, 10, 23-34.

https://doi.org/10.1016/0022-0981(86)90123-1

[31] Allen, D.M., Hudson, J.H. and Costello, T.J. (1980) Postlarval Shrimp (Penaeus) in the Florida Keys: Species Size, and Seasonal Abundance. Bulletin of Marine, 30, 21-23.

[32] Criales, M.M., Wang, J., Browder, J.A., Robblee, M.B., Jackson, T.L. and Hittle, C. (2006) Variability in Supply and Cross-Shelf Transport of Pink Shrimp (Farfantepenaeus duorarum) Postlarvae into Western Florida Bay. Fishery Bulletin, 104, 60-74.

[33] Blanton, J.O., Verity, P.G., Wenner, E.L., Barans, C.A., Knott, D.M., Stender, B.W. and Wilde, S.B. (2001) Key Factors Influencing the Transport of Shrimp Postlarvae in Southeastern U.S. Estuaries. Final Report to Georgia Sea Grant Program and South Carolina Sea Grant Consortium, 1-42. 